\title{
Managementul paraclinic al infecției cu SARS-CoV-2 la pacientul pediatric
}

\author{
Ana-Maria Davitoiu ${ }^{1,2}$, Sorina Chindris ${ }^{1,2}$, Mirela Silvia Iancu ${ }^{1,2}$, Iulia Țincu ${ }^{1,2}$, \\ Luminița Elena Spatariu ${ }^{1,2}$, Doina Anca Pleşca ${ }^{1,2}$ \\ ${ }^{1}$ Facultatea de Medicină, UMF „Carol Davila“, Bucureşti, România \\ ${ }^{2}$ Spitalul Clinic pentru Copii „Dr. Victor Gomoiu“, Bucureşti, România
}

\begin{abstract}
REZUMAT
Omenirea se confruntă, după o sută de ani, cu o nouă pandemie, infecţia cu virusul SARS-CoV-2.

Stabilirea unui protocol terapeutic şi managementul paraclinic al infecţiei reprezintă marile provocări ale momentului pentru cadrele medicale din întreaga lume. Lucrarea încearcă să etapizeze metodele de diagnostic şi investigaţiile paraclinice, stabilind corespondenţa în timp între investigaţii şi modificările de laborator şi radiologice.

Stabilirea diagnosticului pozitiv al infecţiei cu SARS-CoV-2 se face utilizând patru metode de testare: metoda moleculară RT-PCR, testarea serologică prin chemiluminiscenţă şi prin metoda ELISA, teste rapide pentru determinarea anticorpilor de tip IgM şi IgG.

Investigațiile de laborator nu sunt specifice bolii, însă studiile au indicat faptul că limfopenia apare la $83 \%$ dintre pacienţii pediatrici internaţi în spital şi confirmaţi cu infecţie cu SARS-CoV-2.

Imagistica nu este recomandată în scop diagnostic sau screening la pacientul cu suspiciune COVID - valoarea predictivă a RT-PCR este de 10 ori mai mare decât a CT pulmonar.

Cuvinte cheie: pandemie, coronavirus, virus SARS-CoV-2, teste RT-PCR, teste serologice
\end{abstract} anticorpi

\section{INTRODUCERE. DATE EPIDEMIOLOGICE}

Pandemia este o epidemie care afectează un număr mare de oameni şi care depăşeşte graniţele internaţionale.

În decursul istoriei omenirii, au existat numeroase pandemii, bolile infecţioase având adesea consecinţe devastatoare. Ciuma, tifosul, holera, febra galbenă, gripa şi tuberculoza sunt unele dintre bolile infecţioase care au făcut ravagii de-a lungul timpului.

În prezent, traversăm o perioadă excepţională, omenirea confruntându-se cu o nouă pandemie, infecţia cu virusul SARS-CoV-2.

Experţii, oamenii de ştiinţă şi epidemiologii analizează evoluţia pandemiei, în timp ce analiştii economici încearcă să anticipeze impactul economic al măsurilor luate de autorităţi din întreaga lume în lupta împotriva COVID-19.

Autorităţile din Wuhan, epicentrul iniţial al focarului de coronavirus din China, au înregistrat primul caz de infecţie în decembrie 2019. În mai puţin de o lună, cercetătorii, printr-un efort concertat, au realizat secvenţierea genomică. Cartografierea genomică ne aduce informaţii complexe referitoare la particularitățile acestui nou tip de coronavirus. Practic, ne confruntăm cu un virus aparţinând familiei Coronavirus, genul Betacoronavirus. Acesta este un virus cu ARN monocatenar cu polaritate pozitivă care determină sindromul acut respirator sever. Virusul a primit numele de SARS-CoV-2, 80\% din secvența lui genomică fiind identică cu a virusului care a determinat în anul 2002 epidemia SARS, epidemie cu un grad mare de contagiozitate şi potenţial ameninţătoare de viaţă prin severitatea manifestărilor clinice produse. În cazul epidemiei SARS, au fost confirmate 8.098 de cazuri, cu o rată a fatalităţii de aproximativ $9 \%$ (1).

Răspândirea infecției cu SARS CoV-2 la nivel mondial a fost impresionantă. Astăzi, ne confruntăm cu peste 7,3 milioane de pacienţi diagnosticaţi şi cu un număr necunoscut, probabil uriaş, de persoane care au trecut prin boală fără a fi diagnosticate şi incluse în 
statisticile existente. Până în prezent, există în lume peste 430.000 decese (3). Primul caz din ţara noastră confirmat cu infecție cu SARS-CoV-2 a fost pe 26 februarie 2020. De atunci şi până în prezent, în România, au fost confirmate peste 22.000 de cazuri şi s-au înregistrat peste 1400 de decese (2).

Din păcate, membrii personalului medical care îngrijeşte pacienţii cu SARS-CoV-2 sunt adesea victimele acestei infecții. Astfel, în sistemul medical de sănătate, 1 din 9 pacienţi infectaţi aparţine personalului medical (2).

\section{CE TREBUIE SĂ ŞTIM DESPRE INFECŢIA CU SARS-COV-2 LA COPIL?}

Din cadrul persoanelor infectate cu SARS-CoV-2, un procent de $1-2 \%$ îl reprezintă copiii, boala afectând inclusiv nou-născuţii şi sugarii. Distribuţia pe grupe de vârstă este asemănătoare în Asia, America şi Europa, procente similare fiind regăsite şi la pacienţii pediatrici din România. Există decese şi în rândul copiilor (3), dar numărul acestora este extrem de redus.

\section{MANAGEMENTUL DIAGNOSTIC AL INFECTIEI CU SARS-COV-2 LA COPIL}

Pentru a stabili diagnosticul de boală COVID-19, trebuie efectuată testarea pentru identificarea infecției SARS-CoV-2.

Institutul Naţional de Sănătate Publică, prin actualizarea din 28 aprilie 2020, recomandă testarea cazurilor suspecte conform definiţiei de caz pentru sindrom respirator acut cu noul coronavirus (COVID-19) (2). În figura 1 este prezentată metodologia de testare în concordanță cu recomandările Institutului Naţional de Sănătate Publică.

Definiţia de caz suspect ia în discuţie 2 aspecte: contextul epidemiologic şi simptomatologia. Contextul epidemiologic abordează aspecte extrem de bine definite care vizează istoricul de călătorie, contactul cu persoane suspecte sau confirmate şi analizează apartenenţa la clustere sociale. Cel de-al doilea aspect, al manifestărilor clinice, abordează persoanele de orice vârstă care asociază triada clinică febră, tuse, dificultăţi de respiraţie (2).

Cazul suspect, selectat conform definiţiei de caz pentru sindromul respirator acut cu noul coronavirus, va fi testat prin metoda de amplificare a acizilor nucleici, real-time PCR (RT-PCR). Un rezultat pozitiv la testarea RT-PCR transformă cazul suspect în caz confirmat, definit ca persoana cu confirmare de laborator a infecţiei cu SARS-CoV-2 indiferent de prezenţa sau absenţa semnelor şi simptomelor clinice (2).

De precizat că, în cazul pacienţilor pediatrici, aceştia prezintă cel mai adesea la debut o simptomatologie respiratorie caracterizată prin febră, tuse, dificultăţi respiratorii, tablou clinic superpozabil adultului (2). Un procent important dintre copii poate prezenta la debut manifestări digestive nespecifice, manifestări neurologice, manifestări eruptive şi leziuni cutanate (4). Astfel, cunoaşterea acestor forme atipice de debut îl ajută pe clinician să stabilească corelaţia dintre debutul nespecific al bolii (în afară definiţiei de caz suspect) şi infecţia cu SARS-CoV-2.

Stabilirea diagnosticului pozitiv al infecţiei cu SARS-CoV-2 se face utilizând patru metode de testare: metoda moleculară RT-PCR, testarea serologică prin chemiluminiscenţă şi prin metoda ELISA, teste rapide pentru determinarea anticorpilor de tip IgM şi $\operatorname{IgG}(5)$.

\section{RT-PCR}

Reverse transcriptase polymerase chain reaction (RT-PCR) este considerată metoda "gold standard" de diagnostic a infecţiei cu virusul SARS-CoV-2. Testul are o înaltă specificitate şi o sensibilitate până la $98 \%$ (6).

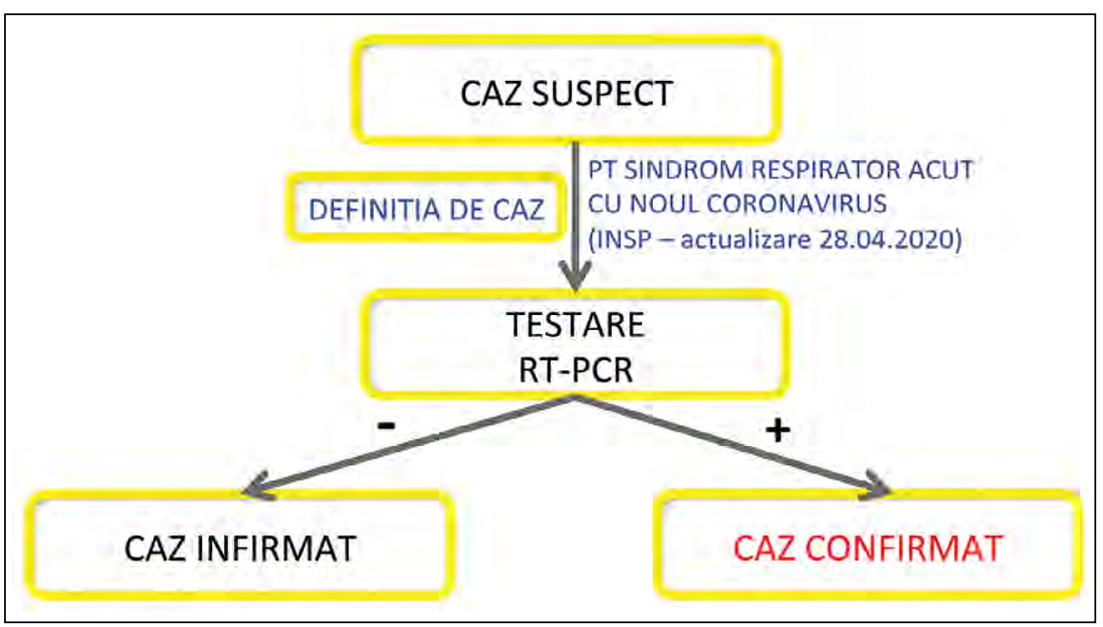


Testarea utilizează material biologic recoltat de la nivelul căilor aeriene superioare (exsudat nazofaringian/orofaringian) sau din căile aeriene inferioare (spută, aspirat traheal, lavaj traheobronşic) în cazul pacienţilor cu afectare respiratorie acută severă (1).

Medicii care lucrează cu pacienţi încadraţi drept cazuri suspecte COVID-19 cunosc importanţa decizională a acestor rezultate în managementul ulterior al pacientului. Durata de prelucrare a probelor prin RT-PCR, până la obţinerea rezultatelor, este de aproximativ 4 ore.

Există riscul de reacţie fals negativă, motiv pentru care metodologia furnizată de către Institutul Naţional de Sănătate Publică stabilește repetarea testării prin efectuarea a 2 teste la distanță de minimum 24 ore între ele.

\section{Testele serologice pentru anticorpi}

Cea de-a doua metodă de evaluare diagnostică a infecţiei cu SARS-CoV-2 la copil o reprezintă testele serologice pentru anticorpi. Testarea serologică este folosită ca metodă complementară testării RT-PCR. Testarea serologică se poate realiza prin metode cantitative sau calitative.

Testele rapide serologice sunt insuficient validate. Aceste teste pot fi utilizate ca metodă complementară testării RT-PCR, pentru screening serologic sau pentru verificarea răspunsului imun în populaţii mari (5).
Figura 2 ilustrează managementul diagnostic utilizând teste rapide de identificare a infecției cu SARS-CoV-2.

Obţinerea unui rezultat IgM pozitiv încadrează pacientul pediatric ca posibil COVID-19, acesta urmând a fi evaluat clinic şi tratat în spital conform protocolului. Un rezultat IgM negativ va fi validat prin efectuarea RT-PCR, care va confirma sau infirma diagnosticul de COVID-19.

Detectarea prin testarea serologică a anticorpilor de tip IgG arată că o persoană a fost anterior infectată cu virusul SARS-CoV-2. Nu există suficiente date medicale care să susţină asigurarea imunităţii de lungă durată prin anticorpi de tip IgG pentru virusul SARS-CoV-2 (5).

\section{Testele serologice}

Determină prezenţa anticorpilor de tip IgM şi IgG. Anticorpii sunt proteine pe care sistemul imun le produce pentru a se apăra în faţa infecţiei. Ca urmare, dezvoltarea acestor anticorpi se realizează în timp. Astfel, anticorpii de tip IgM pot fi detectaţi în sânge începând cu ziua 7 de la contactul infectant, în timp ce anticorpii de tip IgG apar după ziua 10. Apariţia acestor anticorpi reprezentă un indicator al dezvoltării răspunsului imun şi al recuperării clinice $(7,8)$. În figura 3 este prezentată dinamica utilizării investigaţiilor pentru stabilirea infecţiei cu noul tip de coronavirus.

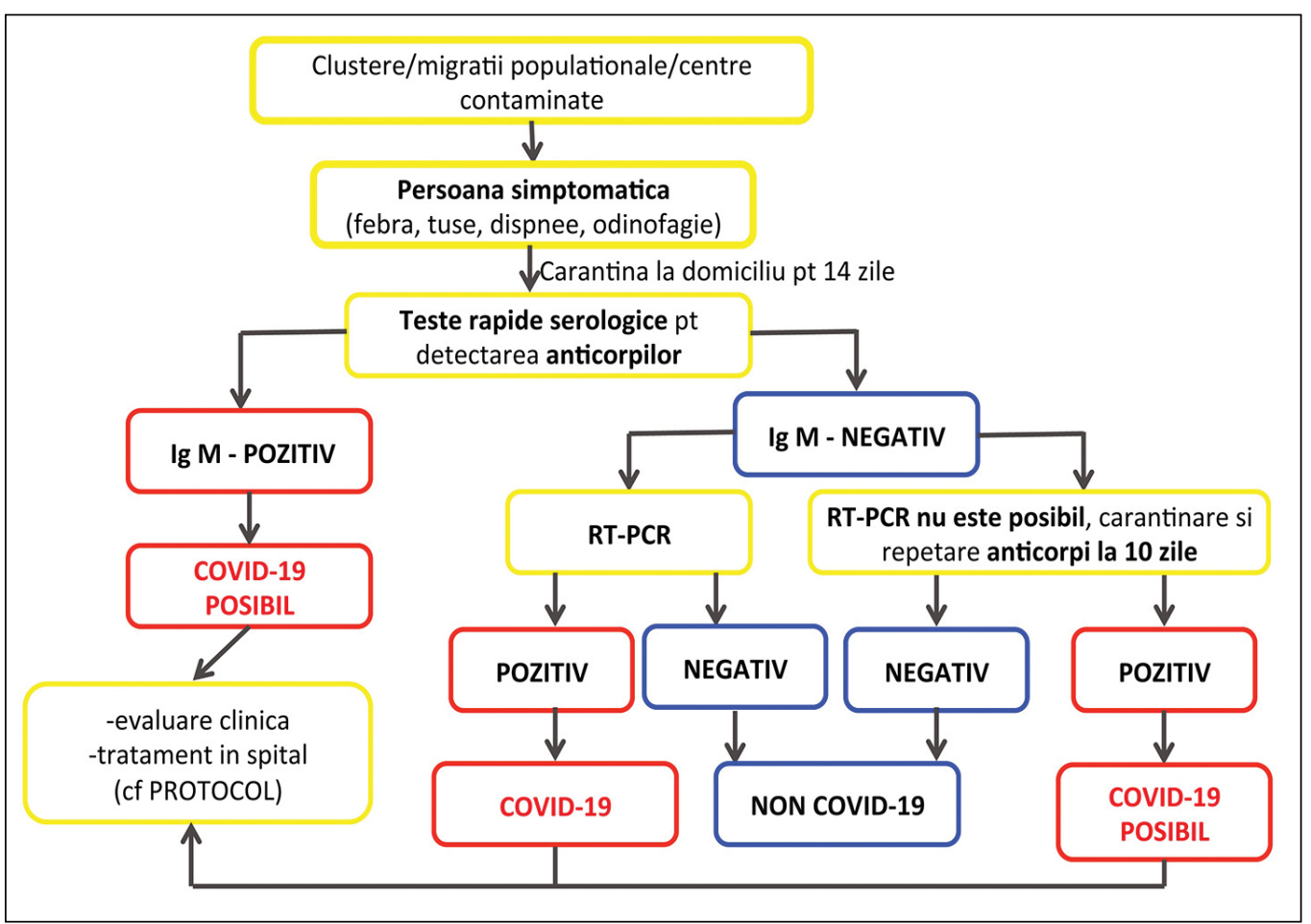

FIGURA 2. Utilizarea testării rapide serologice pentru determinare de anticorpi în clustere/migraţii populaţionale/centre contaminate - adaptare după (5) 


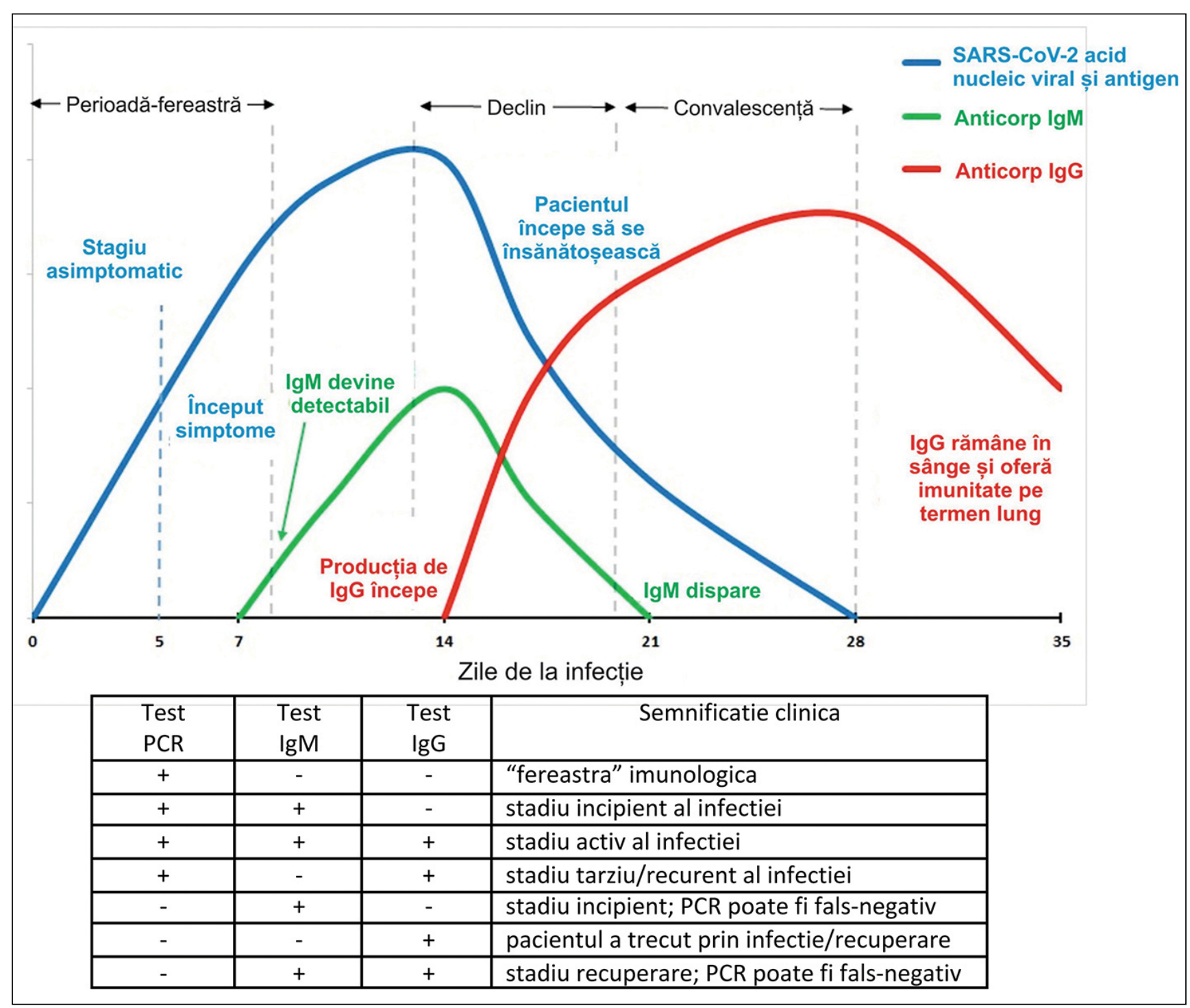

FIGURA 3. Dinamica utilizării investigaţiilor pentru stabilirea diagnosticului în infecţia cu SARS-CoV-2 - adaptat după CliniSciences (8)

Această limită a testului îl face util în scop de cercetare şi pentru clustere şi migraţii largi ale populaţiei (5).

Testarea serologică este o metodă de diagnostic care poate fi folosită pentru evaluarea prevalenţei infecţiei cu virusul SARS-CoV-2. Informaţiile furnizate de testarea serologică au atât importanţă medicală, cât şi socio-economică. Astfel, ele pot fi utilizate pe scară largă pentru elaborarea unor strategii de relaxare a măsurilor impuse de distanţare socială şi, implicit, la relansarea economiei (7).

\section{INVESTIGAŢIILE DE LABORATOR}

Sunt investigaţiile pe care le efectuăm pacienţilor pediatrici suspecţi pentru infecţia cu SARS-CoV-2 internaţi în spital, până în momentul în care testele RT-PCR confirmă sau infirmă infecţia.

Investigaţiile de laborator nu sunt specifice bolii, însă studiile au indicat faptul că cei mai mulţi dintre pacienţii internaţi în spital, confirmaţi ulterior cu infecţie cu SARS-CoV-2, au prezentat modificări ale hemogramei, markerilor inflamatori (CRP, VSH), D-dimerilor, feritinei, procalcitoninei, glicemiei, transaminazelor, creatinfosfokinazei, lactatdehidrogenazei etc. $(5,9)$.

Deoarece coinfecţiile sunt posibile, pacienţii care îndeplinesc definiţia de caz trebuie testaţi pentru infecţia cu virusul SARS-CoV-2 indiferent de prezenţa unui alt patogen respirator.

Limfopenia este modificarea hematologică asociată infecţiei SARS-CoV-2 care apare la aproximativ 83\% dintre pacienţii pediatrici internaţi (5).

Pacienţii cu evoluţie severă a bolii COVID-19 prezintă asocierea limfopeniei cu neutrofilia, precum și cu valori crescute ale transaminazelor, creatinfosfokinazei, lactatdehidrogenazei, CRP, feritinei (5).

Mortalitatea şi morbiditatea în rândul populaţiei pediatrice diagnosticate $\mathrm{cu}$ infecţie $\mathrm{cu}$ virusul 
SARS-CoV-2 sunt direct proporţionale cu valorile crescute ale D-dimerilor şi cu valorile limfopeniei. De asemenea, pacienţii din terapie intensivă care asociază prognostic nefavorabil au adesea valori crescute ale procalcitoninei, în timp ce pacienţii cu stare critică (cu posibilă afecţiune imunologică subiacentă) prezintă valori crescute ale markerilor nespecifici inflamatori (5).

\section{IMAGISTICA ÎN INFECTIA CU SARS-COV-2 LA COPIL}

Utilizarea informaţiilor furnizate de evaluările imagistice la pacientul infectat cu virusul SARS-CoV-2 rămân, după tratament, cel mai controversat aspect în cadrul actualei pandemii.

\section{Principii generale de utilizare a imagisticii la pacienţii pediatrici cu infecţie cu virusul SARS-CoV-2 (10)}

- nu se recomandă evaluare imagistică în scop diagnostic/screening la pacientul cu suspiciune COVID (valoarea predictivă a RT-PCR este de 10 ori mai mare decât a CT pulmonar)

- nu se recomandă evaluare imagistică la pacienţii cu suspiciune/forme uşoare de boală

- evaluarea imagistică este rezervată pacienţilor cu evoluţie nesatisfăcătoare a statusului respirator

- evaluarea imagistică este utilă în monitorizarea apariției, precum și a evoluţiei complicaţiilor bolii

Investigaţiile imagistice care pot fi utilizate în scop diagnostic la pacientul pediatric cu infecţie cu virusul SARS-CoV-2 sunt: radiografia pulmonară, examenul computer tomograf, ecografia toracică.

Dacă se recurge la evaluarea imagistică, radiografia plană este de primă intenţie (5).

\section{Radiografia pulmonară}

Nu prezintă modificări la debut şi în formele uşoare de boală, motive pentru care nu trebuie recomandată de rutină.

În cazul pacienţilor pediatrici diagnosticaţi cu infecţie cu virusul SARS-CoV-2 şi internaţi în spital, evaluarea imagistică permite identificarea unor modificări radiologice în procent de $69-80 \%$. Leziunile maxime apar în ziua 10-12 de la debutul bolii (11). Leziunile pulmonare decelate radiologic sunt frecvent localizate bilateral, periferice, ocupând cel mai adesea bazele pulmonare, având aspectul de opacităţi pulmonare neomogene $(10,11)$.

Discrepanţa dintre afectarea parenchimului pulmonar şi efuziunile pulmonare reduse este notabilă (11).

Dacă se recurge la efectuarea radiografiei pulmonare, se recomandă:

- utilizarea aparatelor portabile (deplasabile la patul bolnavului),

- utilizarea echipamentului personal de protecţie,

- dezinfectarea echipamentului folosit (există posibilitatea ca virusul să rămână pe echipament şi suprafețe până la 72 ore).

La copil, atât radiografia, cât şi examenul computer tomograf pulmonar furnizează imagini de penumonie atipică sau organizată, adesea multilobară şi/ sau bilaterală $(10,11)$.

\section{Examenul computer tomograf pulmonar}

$\mathrm{Nu}$ există modificări specifice pulmonare evidenţiabile prin examen computer tomograf.

La debut, se observă opacităţi pulmonare cu aspect ,în geam mat" localizate bilateral, predominant periferic, fără aspect nodular, de adenopatie sau de pleurezie. În dinamică, pe măsură ce afectarea pulmonară progresează, se modifică arhitectura pulmonară, cu confluarea opacităţilor şi cu apariţia bronşiectaziilor (10).

La pacientul pediatric, aspectele obţinute prin computer tomografie sunt similare celor descrise mai sus, însă de mai mică amploare comparativ cu cele regăsite la adulţi. În plus, o dată cu remisia bolii (5), se constată o restituţie integrală pulmonară.

Examenul CT nu este utilizat în screening-ul primar al bolii. Efectuarea de rutină a examenului CT pulmonar unor cohorte largi de pacienţi presupune resurse finaciare mari (cost/manevră şi echipament de protecţie), risc mare de transmisie a bolii către personalul medical şi auxiliar şi către alţi pacienţi aflați în incinta departamentelor de radiologie.

\section{CONCLUZII}

Stabilirea managementului paraclinic corect pentru diagnosticul infecţiei cu SARS-CoV-2 permite stabilirea rapidă şi precisă a diagnosticului, cu posibilitate de utilizare în cazul pacientului suspect din întreaga lume. Cercetările medicale asidue din această perioadă vor stabili un protocol terapeutic unic, în măsură să salveze vieţi.

Conflict of interest: none declared Financial support: none declared 


\section{BIBLIOGRAFIE}

1. World Health Organisation https://www.who.int/ith/diseases/sars/en - SARS Severe Acute Respiratory Syndrome.

2. Institutul National de Sanatate Publica - http://www.cnscbt.ro/ Infectia cu noul coronavirus SARS-CoV-2.

3. Worldometers.com.

4. Deville JG, Song E et al. Coronavirus disease 2019 (COVID-19): Considerations in children. Uptodate. 2020.

5. Shastri DD et al. COVID 19 second bulletin. Indian Academy of Pediatrics. 2020:5-60.

6. Watson J, Whiting PF et al. Interpreting a COVID-19 test result. BMJ. 2020.

7. Zhengtu Li et al. Development and clinical application of a rapid IgM-IgG combined antibody test for SARS-CoV-2 infection diagnosis. J Med Virology. 2020.

8. SARS-CoV-2 (COVID-19): Diagnosis by IgG/lgM Rapid Test. CliniSciences. 2020. Available at https://www.clinisciences.com/it/ read/newsletter-26/sars-cov-2-covid-19-diagnosis-by-2264.html.

9. TinkuJ, Moslehi MA (Chief Editors). International pulmonologist's consensus on COVID-19. Available at https://www.unah.edu.hn/ dmsdocument/9674-consenso-internacional-de-neumologos-sobrecovid-19-version-ingles.

10. Bickle I, Bell DJ et al. COVID-19. Radiopedia. 2020.

11. Kanne JP, Chung JH et al. Essentials for Radiologists on COVID-19: An Update - Radiology Scientific Expert Panel. Radiology. 2020. 